\title{
TOURISM AND GENDER RESEARCH IN BRAZIL AND MEXICO
}

\author{
ISIS ARLENE DÍAZ-CARRIÓN* AND PAOLA VIZCAINO-SUÁREZ† \\ *Facultad de Turismo y Mercadotecnia, Universidad Autónoma de Baja California, Tijuana (B.C.), Mexico \\ $\dagger$ Faculty of Management, Bournemouth University, Bournemouth, UK
}

\begin{abstract}
Tourism and gender research emerged during the 1990s in the Anglophone academies. Despite the sociocultural improvement in gender studies, tourism and gender research remains a marginal and disarticulated subfield of studies three decades later, with limited impact on the broader tourism scholarship and on practical transformations at the destination level. In Latin America, tourism gender research was introduced towards the beginning of the 21 st century and, apart from the limitations identified in the Anglophone academies, the lack of engagement with gender and feminist debates has contributed to marginalize this subfield of research. The gender dimensions of tourism have been examined mainly through social science frameworks. Even though tourism has been considered an interdisciplinary field of study, gender mainstreaming has been neglected as a relevant approach to research. Despite its limitations, tourism gender research in Latin America has made power relations visible in a wide array of tourism practices. The introduction of gender perspectives has facilitated the analysis of other hierarchical categories such as race, ethnicity, class, or sexual orientation. Drawing insights from a recent bibliometric analysis of the tourism and gender scholarship in Latin America for the period 2001-2015, this article continues a previous work and focuses on the production of the two leading countries in the region: Brazil and Mexico. Content analysis was conducted on a selection of 107 articles (64 from Brazil and 43 from Mexico). The purpose of the analysis was twofold: first, to identify the main research topics, and second, to examine the links with feminist or gender frameworks. Findings show these links are weak, and opportunities were detected to strengthen the association of tourism research with the social sciences through analysis that incorporate cultural and gender dimensions at the macro- or microlevels. Finally, we discuss areas for interdisciplinary collaboration with feminist traditions, such as intersectionality and transnationalism that may contribute to advance tourism gender research in the region.
\end{abstract}

\section{Key words: Tourism; Gender; Research; Sociocultural dynamics; Brazil; Mexico}

\section{Introduction}

According to Bachmann-Medick (2016), the social sciences appear to be unfolding in a dynamic panorama of cultural turns, which entails the "ability to form new conceptual research perspectives that cut across disciplines" (p. 18). The social sciences' capacity to adapt has long been considered essential for the development of knowledge necessary to live in societies characterized by rapid 
change (Becker, 1965). Such flexibility continues to be regarded as one of the social sciences' main strengths (Babb, 2012; Jiménez-Esquinas, 2017). The dynamism of cultural research is a critical question for the social sciences (Kashima, 2014; Platenkamp \& Botterill, 2013) and for gender studies in particular (Figueroa-Domecq, Pritchard, Segovia-Pérez, Morgan, \& Villacé-Molinero, 2015). Gender studies are an example of an interdisciplinary field, developed mainly within the humanities and the social sciences, which focuses on the sociocultural constructions of femininity and masculinity. The field is characterized by its "synergy between thought and activism" (Woodward \& Woodward, 2015, p. 2).

The roots of gender studies go back to women's studies, which emerged from the feminist movements for social change in the US and other Western countries around the 1960s-1970s, spreading across Latin American universities during the 1980s-1990s (Femenías, 2009). Gender studies have brought issues traditionally deemed as private to the forefront of academic discussions, including the everyday life, subjectivity, sexuality, and identity, thus contributing to contemporary debates on democracy, diversity, and equality. From an epistemological point of view, gender and feminist research has contributed to questioning the Western and masculine conceptions of knowledge in academia, highlighting the need to include "other" knowledges and ways of knowing (Rebolledo, 2001, pp. 81-82). This selective process (Kashima, 2014) has been a source of cultural dynamism and has enriched the interpretations of tourism gender research. Since the mid-1990s, the incorporation of gender and feminist perspectives in tourism research has contributed to opening new areas of inquiry, including ethical questions related to the sexualization of tourism spaces, or the (re)production of social and gender inequalities in tourism processes. Despite its relevant contributions, tourism gender research has faced contestation from the structures that dictate what is and how to produce "proper" knowledge (for a recent debate see Munar, Khoo-Lattimore, Chambers, \& Biran, 2017). The dominance of postpositivist approaches, lack of funding, and the perception that gender is not a "serious" topic for research (Pritchard \& Morgan, 2007) are among the institutional obstacles that hinder the advancement of gender research in tourism academia. Within the subfield, scholars have recognized the need for greater engagement with theoretical debates in the social sciences, especially with feminist and other critical theories (Babb, 2012; Jiménez-Esquinas, 2017; Small, Harris, \& Wilson, 2017) and for the inclusion of nonWestern perspectives in knowledge production (Yang, Khoo-Lattimore, \& Arcodia, 2017).

This article is a continued effort of a previous analysis (Vizcaino-Suárez \& Díaz-Carrión, 2018) and seeks to contribute to the construction of a more inclusive subfield, through the examination of Latin American tourism and gender scholarship by concentrating in Brazil's and Mexico's theoretical contributions. Despite its embryonic state, tourism and gender research in Latin America has facilitated the analysis of tourism's interactions with hierarchical categories such as race, ethnicity, class, or sexual orientation. Feminist theorization in the region has drawn from the contributions of Bourdieu, Foucault, Freire, or Butler. Sociologist Pierre Bourdieu has been a significant influence for feminist scholars like Marcela Lagarde and Marta Lamas (from Mexico), or Guacira Lopes Louro and Adriana Piscitelli (from Brazil). Feminist concepts carry an enormous potential for political transformation in a region characterized by social and economic inequalities. According to Costa, Breda, Bakas, and Durão (2016) the formulation of alternative conceptualizations to gendered economic structures is essential to: "challenging mainstream economic theorizing and questioning the relationship between power and knowledge" (p. 112).

Latin American feminists consider patriarchy, capitalism, and neoliberalism as the main causes behind segregation, exclusion, and inequality. Gender differences in the region not only respond to distinct gender systems that undervalue women's sociocultural, political, or economic contributions, but also to intersecting oppressions linked to race, ethnicity, class, or sexual orientation (Babb, 2012). All these categories contribute to aggravate gender differences (Carosio, 2009), in a region where tourism has experienced continued growth and is increasingly dependent on women's labor. Tourism processes have transformed gender roles at the microlevel as a result of macrolevel trends mainly related to economic forces (Organización Mundial 
del Turismo [OMT], 2016; Organización Mundial del Turismo [OMT] \& ONU Mujeres, 2010).

The article aims to explore the engagement of Latin American tourism gender research with feminist traditions. We build from a bibliometric analysis conducted in 2016, in the three main Latin American scientific indexes (Redalyc, Scielo, and Latindex), for the period 2001-2015, which had the purpose of providing a profile of the Latin American tourism gender research. This article adds to the authors' previous analysis by focusing on the production of the two leading Latin American countries in the subfield: Brazil (64 articles, or $41.83 \%$ of the sample) and Mexico (43 articles, or $28.10 \%$ ). Content analysis was conducted on the Brazilian and Mexican papers with the purpose of: a) identifying the main research topics and gender categories; $b$ ) examining the studies' engagement with feminist and gender frameworks; and c) inquiring into the cultural dynamics in relation to feminist and gender contexts. Research topics reflect the preoccupation with persistent inequalities in the region, due to a history of colonialism and exploitation of women, indigenous people, afro-descendant communities, and other minorities, in favor of the appropriation of territories and accumulation of the capitalist markets (Guillamón \& Ruiz, 2015; Marín-Guardado, 2015). After examining other relevant aspects, such as gender categories, methods, and theory-building efforts, the main theoretical and methodological contributions from contemporary feminism and the social sciences are discussed. We conclude by proposing some steps towards increasing the engagement between tourism gender research and the social sciences, as well as incorporating innovative feminist tools.

\section{Gender in Tourism Research}

Tourism processes interact with complex and varied social realities, where the relationships between individuals, groups, and organizations tend to be hierarchical and often unequal (Swain, 2005). Issues related to differences and inequalities in tourism processes that stem from gender relations can be found in the sexual division of labor, the control of natural and cultural resources, the form in which societies construct "otherness," and the varied experiences of hosts and guests (Cohen
\& Cohen, 2012; Jappelli, Nappi, \& Torrini, 2017; Platenkamp \& Botterill, 2013).

The dominant theorization on tourism practices historically overlooked the gender differences and identities represented in tourism consumption, production, and promotion. Such "gender neutral" research has had the negative effect of reinforcing the masculine, rational, and positivist constructions of tourism researchers (Aitchison, 2009; Johnston, 2001; Pritchard \& Morgan, 2000). Following Henderson (1994), Swain (1995) identified five phases that have characterized gender research in tourism: 1) no women; 2) the compensatory "add women and stir"; 3 ) the focus on "sex differences" between men and women; 4) the feminist or "women-centered"; and 5) gender scholarship (pp. 253-254). Those phases depict the evolution of gender as a category of analysis in tourism and gender research.

Gender scholarship in tourism gained international attention in the mid-1990s, with a series of articles, edited books, and special journal issues dedicated to examining the gender dimensions of tourism development, the behavior and interactions of gendered tourists and hosts, and gendered work in tourism (see Kinnaird \& Hall, 1994; Norris \& Wall, 1994; Swain, 1995; Sinclair, 1997). A few of these studies explored women as producers and consumers of tourism in Latin America and other developing regions (e.g., Casellas \& Holcomb, 2001; Chant, 1997; Henrici, 2002).

The first Latin American tourism and gender articles were published in the early 2000s, employing frameworks from the social sciences and drawing insights from the global literature. Early themes revolved around women's participation in tourism projects (e.g., ecotourism, handicrafts) and the relationship between tourism and sexuality (MartínezCorona, 2003; Piscitelli, 2002; Ramos-Maza, 2004). In the past decade, Latin American tourism and gender scholars have focused on addressing inequalities from an economic and sociocultural approach. The scant interest in the gendered experiences of tourists stands in contrast with the Anglophone literature on gender differences in tourism and leisure (Figueroa-Domecq et al., 2015; Henderson \& Gibson, 2013; Small et al., 2017).

The subfield has established the need to analyze the gender dynamics of tourism, recognizing that 
tourism is part of wider sociocultural, ecological, and political processes (Babb, 2012; Cole \& Morgan, 2010). According to Kashima (2014), a cultural dynamics perspective can facilitate the identification of change, persistence, and transformative processes. Such a perspective can contribute to the tourism and gender scholarships through the analysis of the mechanisms that reproduce gender inequalities, and the main drivers for cultural change. The legislative revisions introduced in Latin America over the past couple of decades have called for gender mainstreaming in development policies, including those pertaining to tourism. However, tourism research has yet to meet the growing demand of knowledge production with a gender perspective (Vizcaino-Suárez, SerranoBarquín, Cruz-Jiménez \& Pastor-Alfonso, 2014).

\section{Methodology}

Bibliometric analysis has proven useful to assess the development of tourism scholarship (Hall, 2011). Tourism and gender scholars have employed bibliometric methods to examine the subfield's trends through the identification of relevant journal articles (Figueroa-Domecq et al., 2015; Small et al., 2017). This study draws from a 2016 bibliometric analysis of the publications on tourism and gender research conducted in the largest scientific databases in Latin America (Redalyc, Scielo, and Latindex), where the main working languages are Spanish and Portuguese. These regional sources were selected over leading international databases such as Scopus or the ISI Web of Knowledge, because the latter have incomplete coverage of non-English sources. The methodology for the bibliometric analysis entailed: selecting the databases; identifying keywords for the search criteria; defining the variables to be analyzed; classifying research topics, methodologies, and theoretical frameworks. The main keywords were tourism or tourist, and gender. A list of terms related to gender identities, sexuality, and tourism was also included (Henderson \& Gibson, 2013; Swain, 2005). Bibliometric studies that employ lists of keywords allow for exhaustive searches in tourism and nontourism journals, even though a drawback is to encounter some results that may not focus on tourism (CorralMarfil \& Cànoves-Valiente, 2013). The list of keywords is presented below. All terms were introduced in Spanish, Portuguese, and English:

- women, woman, men, man, female, male, children, girls, boys, feminine, masculine, homosexual, gay, lesbian, LGBT, queer, transgender, transsexual;

- enterprise, entrepreneur, cooperatives, business, hotel;

- handicraft, artisan, heritage;

- empowerment, change, transformation, participation, sustainability;

- body, embodiment, eroticism, exotism;

- migration, prostitution, sex tourism;

- ethnicity, aboriginal, pueblo, people, indigenous, indigena, race, AfroAmerican, Afroamerican, Afro*, mestizo, mestiz*, local communit*

After eliminating duplicates, 153 gender-aware papers were identified from 70 journals for the period 2001-2015. The search was limited to indexed journals with online access to facilitate the downloading and reading of full papers. The analysis focused on academic papers and excluded books, conference proceedings, white papers, and other knowledge transfer materials, as has been the standard in other studies (Corral-Marfil \& Cànoves-Valiente, 2013; Figueroa-Domecq et al., 2015; Jappelli et al., 2017; Small et al., 2017). After an analysis per country, Brazil and Mexico emerged as the top two countries in the region, with a joint production of 107 articles $(69.9 \%$ of the total); consequently, the authors decided to focus the analysis of the papers from these two countries and limited the content analysis to Brazil and Mexico, including a few international collaborations: Brazil-Netherlands (1), Brazil-France

(1), Brazil-French Guiana (1), Mexico-US (2), Mexico-Belgium (2) and Mexico-Cuba (1).

Of the total articles, 64 papers $(41.83 \%)$ were authored by Brazilian scholars and 43 (28.10\%) were authored by Mexican researchers (see Fig. 1). The purpose of content analysis was to identify the main research topics along with methodology, gender categories, and references to the feminist and gender literatures to revise theoretical frameworks. After reading the articles produced in Brazil and Mexico, research topics were grouped following the categories proposed by Figueroa-Domecq et al. 


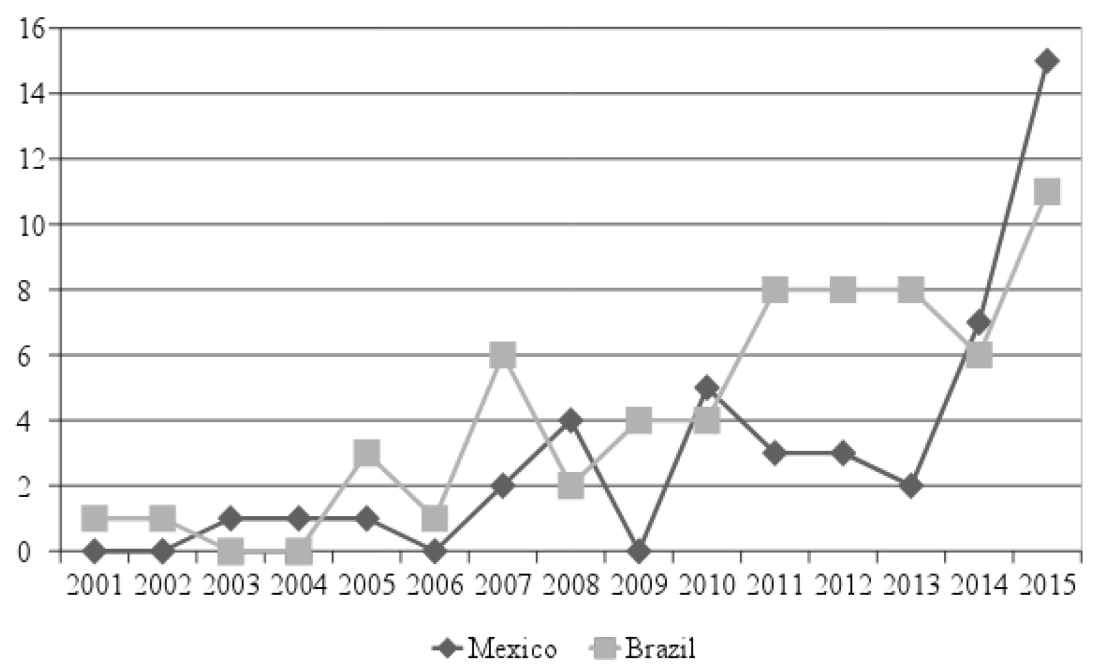

Figure 1. Tourism and gender research in Brazil and Mexico (2001-2015).

(2015): 1) Gendered tourists, 2) Gendered hosts, 3) Gendered labor, and 4) Theory research \& education (see Table 1). The aforementioned categories, as well as their respective individual topics, were employed to facilitate comparison with international studies.

\section{Findings}

In their bibliometric analysis of tourism gender research in international indexes (Scopus and the ISI Web of Knowledge), Figueroa-Domecq et al. (2015) found "Gendered tourist" to be the main topic $(46.1 \%)$ explored by critical studies, followed by "Gendered hosts" (26.4\%). The most studied individual topics, for these categories were "Consumer behavior, decision-making and motivation" and "Tourism, gender, and development," respectively.

In the Brazilian and Mexican analyses, the most recurrent topic is "Gendered hosts" (27.1\% for Brazil and $17.8 \%$ for Mexico); the preponderance of "Gendered hosts" as a topic for tourism gender research is likely related to the conceptualization of both nations as host countries (OMT, 2016). A second level analysis reveals differences between the themes and topics pursued by Brazilian and Mexican scholars. For example, while Brazilian academics have paid more attention to the "Gendered tourists" category (15.9\%), Mexican researchers have devoted more efforts to the exploration of "Gendered labor" (13.1\%). "Perceptions of tourism destination and product images" (4.7\%), "Sex tourism, sexual violence, and exploitation" (15.9\%), "Gender discrimination and occupational segregation" (4.7\%) and "Tourism, gender, and theory" $(8.4 \%)$ were the most salient individual topics in each of the four main categories in Brazilian studies. In the case of Mexico, these were "Medical, cosmetic, and reproductive tourism" (2.8\%), "Sex tourism, sexual violence, and exploitation" (11.2\%), "Gender discrimination and occupational segregation," (11.2\%) and "Tourism studies" (2.8\%).

Concerning gender categories, $79 \%$ of articles use the women/men binary (see Fig. 2). This traditional category is employed more frequently in papers published during the initial years of tourism gender research, with the majority of studies focusing on "women." With respect to methodological approaches, $63 \%$ of the papers adopted a qualitative methodology; $17 \%$ were theoretical/ historical studies, $14 \%$ employed a quantitative methodology (mainly descriptive statistics), and $6 \%$ used a mixed-methods approach. According to Figueroa-Domecq et al. (2015), findings suggest that quantitative approaches are more predominant in gender and tourism research, representing $40.1 \%$ of the studies analyzed. However, for Wilson 
Table 1

Tourism and Gender Research Topics in Brazil and Mexico

\begin{tabular}{|c|c|c|}
\hline Research Topic & $\begin{array}{c}\text { Brazil } \\
\text { [No. (\%) of Papers] }\end{array}$ & $\begin{array}{c}\text { Mexico } \\
{[\text { No. }(\%) \text { of Papers }]}\end{array}$ \\
\hline \multicolumn{3}{|l|}{ Gendered tourists } \\
\hline Consumer behavior, decision-making, and motivation & $1(0.9)$ & $0(0.0)$ \\
\hline Sex/romance tourism & $1(0.9)$ & $0(0.0)$ \\
\hline Rural tourism \& ecotourism & $2(1.9)$ & $0(0.0)$ \\
\hline Perceptions of tourism destination $\&$ product images & $5(4.7)$ & $0(0.0)$ \\
\hline Market segmentation \& marketing/designing for women & $0(0.0)$ & $0(0.0)$ \\
\hline Risk perception & $0(0.0)$ & $0(0.0)$ \\
\hline Medical, cosmetic, \& reproductive tourism & $3(2.8)$ & $3(2.8)$ \\
\hline Gay, lesbian, \& transexual tourism & $2(1.9)$ & $0(0.0)$ \\
\hline Tourist typologies & $3(2.8)$ & $1(0.9)$ \\
\hline Tourist experiences & $0(0.0)$ & $0(0.0)$ \\
\hline Subtotal & $17(15.9)$ & $4(3.7)$ \\
\hline \multicolumn{3}{|l|}{ Gendered hosts } \\
\hline Tourism, gender, \& development & $8(7.5)$ & $4(3.7)$ \\
\hline Residents' attitudes, \& perceptions & $3(2.8)$ & $2(1.9)$ \\
\hline Sex tourism, sexual violence, \& exploitation & $17(15.9)$ & $12(11.2)$ \\
\hline Entrepreneurship & $0(0.0)$ & $1(0.9)$ \\
\hline Ethics \& sustainability & $1(0.9)$ & $0(0.0)$ \\
\hline Subtotal & $29(27.1)$ & $19(17.8)$ \\
\hline \multicolumn{3}{|l|}{ Gendered labor } \\
\hline Gender discrimination \& occupational segregation & $5(4.7)$ & $12(11.2)$ \\
\hline Employment development \& female career paths & $3(2.8)$ & $2(1.9)$ \\
\hline Managerial styles \& recruitment processes & $0(0.0)$ & $0(0.0)$ \\
\hline Sexual harassment & $0(0.0)$ & $0(0.0)$ \\
\hline Subtotal & $8(7.5)$ & $14(13.1)$ \\
\hline \multicolumn{3}{|l|}{ Theory research \& education } \\
\hline Tourism studies & $1(0.9)$ & $3(2.8)$ \\
\hline Tourism, gender, \& theory & $9(8.4)$ & $2(1.9)$ \\
\hline Literature reviews & $0(0.0)$ & $0(0.0)$ \\
\hline Academic leadership & $0(0.0)$ & $0(0.0)$ \\
\hline Tourism education & $0(0.0)$ & $0(0.0)$ \\
\hline The impact of gender in tourism & $1(0.9)$ & $1(0.9)$ \\
\hline Sub total & $10(10.3)$ & $6(5.6)$ \\
\hline Total & $64(60.0)$ & $43(40.0)$ \\
\hline
\end{tabular}

and Hollinshead (2015) qualitative methodologies are preferred when addressing: "Critical studies of gender, colour, race, ethnicity, hybridity and the Other" (p. 31). Similarly, Nunkoo, Hall, and Ladsawut (2017) found female authors employ qualitative methodologies more frequently than male authors.

Both findings are also consistent with Small et al. (2017), who observed a preponderance of qualitative approaches in tourism gender research. The preference towards qualitative methodologies is not unique to tourism gender research. Tribe and Xiao (2011) found that $60 \%$ of all papers published in Annals of Tourism Research rely on qualitative methodologies. For the same journal, Nunkoo et al., (2017) observed a dramatic increase
$(42.05 \%)$ in the use of qualitative approaches from 1990 to 2015. The interpretative turn in tourism studies has been critical for understanding diverse tourism realities, despite the hegemony of positivism (Platenkamp \& Botterill, 2013).

Our findings suggest that tourism gender research in Brazil and Mexico has been favored by both the constructivist-interpretative turn, and the suitability of qualitative methodologies for gender research (Nunkoo et al., 2017).

\section{Current Contributions to Tourism and Gender Research From Brazil and Mexico}

The following section takes a closer look at the articles that fall into the top three individual 


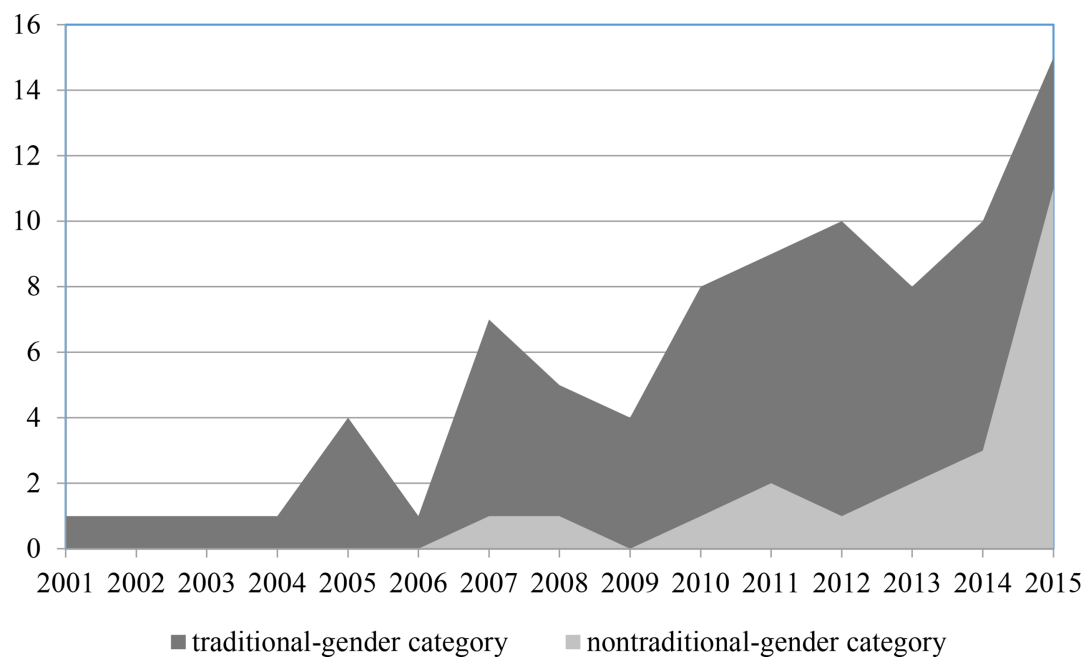

Figure 2. Gender categories in tourism research from Brazil and Mexico (2001-2015).

topics in the tourism gender research in Brazil and Mexico (see Table 1): "Sex tourism, sex violence, and exploitation," "Gender discrimination and occupational segregation," "Tourism, gender, and development," and "Tourism, gender, and theory." The purpose of this discussion is to determine the prevailing incorporation of feminist and gender concepts and theories. We think the adoption of feminist and gender theories is a salient issue that can help develop more consistent frameworks in tourism gender studies in the region to embrace diversity (Babb, 2012; Yang et al., 2017).

\section{Gender, Sex, Exploitation, and Tourism}

The recurrent conceptualization of gender identities as the traditional women/men binary is most evident in Mexican scholarship. However, recent studies have begun to change this trend by considering diverse gender identities, such as gay men (e.g., Arroyo \& Amador, 2015; García-Ortega \& Marín-Poot, 2014; Monterrubio, 2015). On the other hand, Brazilian studies have shown an earlier interest in exploring sexual and gender diversity. The study authored by Vieira (2007) was the first in the sample to include a nontraditional gender category. His paper "Turismo GLBTT na Costa do Cacau: Uma alternativa econômica para o sul da Bahia" examines the appeal of Bahia's Cocoa
Coast for the LGBT tourist segment. Diverse gender and sexual identity categories are common in studies that look at gay-friendly destinations or events (Gentil \& Araujo, 2014; López-López, Gallegos, \& Quintero, 2015).

Recent articles deal with LGBT categories from a prostitution/romance perspective. The 2015 special edition on Tourism and sex between men [in Spanish], published by the Argentinian Journal Estudios y Perspectivas en Turismo, opened a space for the analysis of queer identities and sex tourism. A broader conceptualization of sex tourism in tourism gender scholarship incorporates a range of relationships between hosts and guests, which goes beyond prostitution and include romance, migration, and marriage (Piscitelli, 2007). Sex tourism (either masculine or feminine) is a relevant topic in tourism and gender research in both the Anglophone and Latin American academies. This topic builds on north-south economic inequalities, where international tourists play an important role as consumers (Wonders \& Michalowski, 2001). Studies are beginning to analyze sex tourism in the context of domestic or intraregional flows in Latin America (Córdova-Plaza, 2015). Even though sex tourism was traditionally conceptualized as male consumed, international female sex tourism is becoming more visible. [The authors recommend to review Meisch (1995), a description of sex and romance tourism 
in Ecuador, which has been an important reference for the topic in the region].

Brazilian and Mexican scholars refer to the works of influential Anglophone authors in tourism research, like Dean MacCannell, Erik Cohen, or Malcolm Crick, to structure accounts of travel stories by male sex tourists to Latin American destinations. The analytical frameworks emphasize the concepts of "authenticity" and "exoticism" (Cantalice, 2011; Piscitelli, 2002). In their paper about male gay sex tourism in Mexico City, LópezLópez and Carmona-Mares (2008), drew from the contributions of Michael Hall, Malcom Crick, and Martin Oppermann. In his analysis of female sex tourists and "tropical masculinity" [masculinidade dos trópicos] in Rio Grande do Norte (Brazil), Cantalice (2011) gained insights from Klaus de Albuquerque's work on beach boys and female tourists. Sex tourism has also been conceptualized as a social or health problem, linking prostitution with sexual exploitation. For most of these studies, the theory-building efforts have come mainly from adopting a destination planning approach. The emphasis is placed on destination marketing (Sobreira, Machado, Rebouças, \& Forte, 2014), legal efforts due to the illegal status of prostitution (Marques \& Pinho, 2014), and official control measures (Parriault et al., 2015).

Sex tourism research has predominantly considered the binary category women/men, but is paving the way for the incorporation of nontraditional gender categories. The works of queer theorists Judith Butler, Denis Altman, Gill Valentine, and Jon Binnie are frequently cited in recent papers on the topic. The aforementioned authors are also influential in the construction of analytical frameworks for "Gay, lesbian, and transsexual tourism," which is an emerging topic in the tourism gender subfield of research in the Brazilian academy.

\section{Gender Discrimination and \\ Occupational Segregation}

This individual topic has focused on women as a traditional gender category of study, where ecotourism and rural tourism have been the preferred segments of analysis (Di Ciommo, 2007; DíazCarrión, 2014; Lunardi, de Souza \&, Perurena, 2015; Rodríguez-Muñoz \& Acevedo-Duarte, 2015). This topic is more popular among Mexican scholars, who have sought to evaluate the potential for women's empowerment through their active participation in tourism development initiatives. The studies analyze the obstacles faced by women as tourism workers or entrepreneurs, due to traditional gender roles that assign the burden of domestic and care responsibilities to women. Research from this individual topic also examines interactions of gender with other structures of oppression, like ethnicity. This is particularly evident in papers that focus on handicrafts as a component of the local tourism experience. In such contexts, indigenous women tend to be the main population of study (MartínezCorona, 2003; Ramos-Maza, 2004). Class-based divisions are another important structure of oppression commonly examined (Pérez-Ramírez, ZizumboVillareal, \& Miranda-Contreras, 2012).

Tourism and gender research in the region has made the different interactions between gender, ethnicity, and class visible, showing that tourism is not necessarily contributing to the reduction of inequalities. The subfield of research has broadly drawn from the feminist frameworks proposed by international and regional scholars. Influential authors from the international scholarship are Naila Kabeer, Dianne Rocheleau, Srilatha Batliwala, Jo Rowlands, Janet Henshall-Momsen, Pierre Bourdieu, or Joan Scott. And from the regional academies, widely cited authors are Magdalena León, Marcela Lagarde, Marta Lamas, Teresita de Barbieri, Pilar Alberti, Celia Amorós, Amélia Valcárcel, or Gemma Cànoves. Articles from this individual topic have contributed to establishing linkages between theory and praxis. By analyzing empowerment and its repercussions on gender change, scholars have identified core elements to advance women's status through their participation in tourism either in Brazil or in Mexico (Díaz-Carrión, 2014; Lunardi et al., 2015; Martínez-Corona, 2003).

\section{Tourism, Gender, and Theory}

"Theory in gender and tourism research" as an individual topic reflects advancements and limitations of tourism gender research identified by Figueroa-Domecq et al. (2015). For example, the high prevalence of theorization on sexual tourism among Brazilian and Mexican scholars has 
facilitated the incorporation of nontraditional gender categories (López-López \& van Broeck, 2015; Nascimento-Duarte, 2009). Latin American scholars tend to follow the developments of Anglophone academies to construct their theoretical and epistemological frameworks. This trend can have a negative connotation, since tourism and gender scholars in the region face constraints by highly ranked journals to include references from widely cited research (mostly published in English), to the detriment of local or regional sources (in Spanish and Portuguese).

For example, Mexican and Brazilian scholars in tourism gender research commonly cite the works of Michel Foucault, Pierre Bourdieu, or Judith Butler. But the intertwining of theories and concepts to construct analytical frameworks is a much more complex process than merely citing well-known international sources and eschewing regional ones. As experienced in our practice, Latin American scholars compare, reinterpret, adapt, and construct research frameworks that take into consideration sources from different geographic scopes (international, regional, local) and languages (mainly Spanish, Portuguese, and English). This selection process responds to a cultural dynamics perspective (Kashima, 2014) that facilitates the identification of cultural information that improves the understanding of gender relations. Finally, theorization in tourism research has shown growing interdisciplinary exchange with the social sciences, management and economics. This relationship seems less vibrant in the international subfield of tourism gender research (FigueroaDomecq et al., 2015).

For the scholarly production on tourism and gender in Brazil and Mexico, we also found scant interdisciplinary collaboration and isolation among scholars. Nevertheless, the majority of academics in the region have pursued postgraduate degrees in the social sciences, applying their backgrounds in tourism and gender research. Even when social science or gender scholars are not actively involved as faculty members in tourism programs, some research interaction is already happening. Despite these efforts, we see the need for effective networking both at the institutional and individual levels to continue building bridges between disciplines. The next section proposes a series of critical steps to advance tourism and gender interdisciplinary research.

Social Science Perspective: Feminist Contributions to Tourism and Gender Research

Length limitations prevent us from conducting an exhaustive discussion about the interactions between tourism gender research and the social sciences, but this relation offers a vibrant scenario. Feminist epistemologies are (de)constructing theories and approaches to navigate in postmodern societies where diversity and change are recurrent (Platenkamp \& Botterill, 2013; Swirskya \& Angelonea, 2015).

According to Phillips and Cree (2014), contemporary feminism coexists in a context where equality is still at the core of theory, but "men friendly" and diversity approaches have been incorporated as postmodern values. Furthermore, the social media: "has placed key feminist debates back on the public agenda and to a public that is far more comprehensive than any time before" (p. 941). Accordingly, gender research encompasses a widening intellectual base where intersectionality and cross-cultural acumen open opportunities to face challenges and overcome perceived limitations (Scholz, 2016; Wilson \& Hollinshead, 2015; Woodward \& Woodward, 2015), and to explore the intersectional inequalities of gender, class and nationality or ethnicity in tourism destinations (Cole \& Ferguson, 2015).

Currently, gender research offers theoretical and methodological tools necessary to understand contemporary sociocultural dynamics and construct egalitarian societies (Lagarde, 1996; Woodward \& Woodward, 2015). Feminist traditions in the social sciences can provide a strong epistemological foundation for tourism and gender research in Latin America. Theoretical frameworks that embrace diversity in the social sciences will be helpful to address inequalities, to overcome neocolonialism, and to propose positive transformations in the tourism industries.

\section{Inequality in Tourism: Approaches \\ From the Social Sciences}

Latin America is characterized by inequalities that touch all aspects of life, from the access to 
education, health, and other public services, to land and other asset ownership, and the functioning of credit markets, access to formal labor markets, or political influence and participation (Ferranti et al., 2005). The expansion of tourism has contributed to the reproduction of socioeconomic, territorial, and political inequalities in the region (López-Santillán \& Marín-Guardado, 2010). The tourism industry in Latin America is also dependent on women's work (OMT \& ONU Mujeres, 2010). Overall, tourism research - and more particularly, tourism gender scholarship in the region- has much to gain from the incorporation of contemporary feminist perspectives, to address the prevailing social and gender inequalities. As stated earlier, gender categories are increasingly diverse and the feminist traditions in social sciences provide flexible analytical tools for tourism and gender research. For Figueroa-Domecq et al. (2015), social science and feminist frameworks offer a dynamic set of questions, theories, and methods useful in the analysis of tourism's power structures and networks. Such frameworks open the possibility for a richer reflexive and reflective knowledge catalogue, with beneficial exchanges on methodological designs.

Finally, since inequality is a recurrent theme in tourism and gender research in Latin America, scholars may benefit from the feminist analysis of everyday life as the main arena where inequalities are experienced (Carosio, 2009). Feminism can also provide a robust theoretical body to critically examine undervalued care work, as a core element within households and within the tourism and hospitality industries. Brazilian and Mexican scholars have relied on feminist thinking and social sciences frameworks to address inequality in their research (e.g., Díaz-Carrión, 2014; MartínezCorona, 2003; Piscitelli, 2007). Unlike the prevailing association of tourism research programs with business schools in the Anglophone academies (Inui, Wheeler, \& Lankford, 2006), equivalent programs in Latin America (e.g., Master and Ph.D.) have remained widely associated with faculties in the social sciences. This institutional association presents an opportunity for the region's research programs to promote a closer interaction between tourism, feminism and the social sciences.

\section{Feminism, Neocolonialism, and Tourism in Global Contexts}

According to Scholz (2016), it is important to overcome neocolonialism in feminist thinking and to stop considering women of the Global South as "merely oppressed objects" (p. 95). This requires the fruitful interaction between feminists (North and South) to construct frameworks that explain Latin American women's "counter hegemonic agency" (p. 97). Acknowledging the need for further collaboration, antiracist feminist scholars Falcón and Nash (2015) propose a transnational movement "that is process-oriented rather than outcome oriented" (p. 9) and where intersectionality provides a language and framework "to delve deeper into complex inter-relationships" (p. 2).

Similarly, Vergara-Figueroa and ArboledaHurtado (2014) reflected on the role of race and ethnicity in Latin American contemporary societies, whereas Cole and Ferguson (2015) advocated to examine gendered power relations in localglobal dynamics. We also see these categories (race and ethnicity but also North-South) as central to the analysis of tourism, gender, and inequality in the context of Brazil and Mexico. As an inclusive methodology, intersectionality embraces different voices and promotes diversity, both highly desirable characteristics for tourism and gender studies.

Given that tourism is embedded in a scenario of globalization and capitalism, the incorporation of transnational feminist frameworks would provide fertile ground for the examination of tourism practices that account for different subjectivities and experiences of gender inequality (Falcón \& Nash, 2015; Sassen, 2007; Wilson \& Hollinshead, 2015). Latin American scholars have addressed the global dynamics of tourism development favored either by geographic location or by trade and commercial relations, but diversity is not always integrated in the analysis and some feminist hegemonic discourses remain. As a result, intersectionality and transnational feminist frameworks can be instructive in recognizing the interrelationships of complex social realities in tourism and gender research (Wilson \& Hollinshead, 2015). They can also provide an extended structure to embrace diversity in a wide range of intellectual contexts and theoretical debates (Scholz, 2016). In addition, tourism and 
gender research can deepen its interactions with the social sciences to improve its knowledge base, currently considered as partial and flawed (Figueroa-Domecq et al., 2015).

\section{Conclusion}

Even from its marginal position, tourism and gender research has sought to acknowledge the diversity of theoretical perspectives and ways of experiencing tourism processes. In the past two decades, tourism and gender scholars in Brazil and Mexico have produced a growing body of research that critically looks at the relationships between tourism and inequality, as well as the power interactions between regions (global North-South), organizations (transnational-local), and people (accounting for differences due to hierarchical categories such as gender, class, ethnicity, or sexual orientation). These efforts have had little visibility in the global tourism academy, due to the predominance of English, and have had scant engagement with other critical scholarship within the Latin American academies (mainly due to policies that favor discipline-oriented networks as opposed to interdisciplinary collaborations). Consequently, tourism and gender and its cultural dynamics scholarship in the region is characterized by isolation, marginality, and a lack of structure. These current limitations in the subfield weigh negatively on the potential to exert meaningful social change. However, Brazilian and Mexican scholars have contributed to the understanding of gender cultural dynamics (Kashima, 2014) that intersect with tourism processes at both the micro- (e.g., lived experience) and macrolevels (e.g., global North-South relations) of analysis.

As this study has shown, there is a set of particular interests to further collaboration to enrich critical studies embedded in global dynamics but also addressing local realities. Tourism and gender research could take advantage of Anglophone Academies by the time it is also able to propose its own theoretical knowledge in some subthemes of study already revisited (as care work, diverse gender identities, or ethnic inequalities) and other few examined but relevant (Theory research \& education). A closer interaction of tourism and gender research with the social sciences and with contemporary feminist epistemologies can be very helpful to bring together theory and practice to challenge social and gender inequalities in the Latin American region and elsewhere.

\section{References}

Aitchison, C. (2009). Gender and tourism discourses: Advancing the gender project in tourism studies. In T. Jamal \& M. Robinson (Eds.), The SAGE handbook of tourism studies (pp. 631-644). Thousand Oaks, CA: Sage Publications.

Arroyo, L., \& Amador, K. (2015). Turismo y trabajo sexual masculino en Cancún-México. Estudios y perspectivas en turismo, 24(4), 982-992.

Babb, F. E. (2012). Theorizing gender, race, and cultural tourism in Latin America. A view from Peru and Mexico. Latin American Perspectives, 39(6), 36-50.

Bachmann-Medick, D. (2016). Cultural turns: New orientations in the study of culture. Berlin, Germany: Walter de Gruyter GmbH \& Co KG.

Becker, J. M. (1965). Emerging trends in the social studies. Educational Leadership, 22(5), 317-359.

Cantalice, T. (2011). O melhor do Brasil é o brasileiro! Corpo, identidade, desejo e poder. Sexualidad, Salud y Sociedad REVISTA LATINOAMERICANA, 7(abr.), 69-102.

Carosio, A. (2009). Feminismo latinoamericano: Imperativo ético para la emancipación. In A. Girón (Ed.), Género y globalización (pp. 229-252). Buenos Aires, Argentina: CLACSO.

Casellas, A., \& Holcomb, B. (2001). Gender, tourism and development in Latin America. In Y. Apostolopoulos, S. Sönmez, \& D. J. Timothy (Eds.), Women as producers and consumers of tourism (pp. 143-166). Westport, CT: Praeger.

Chant, S. (1997). Gender and tourism employment in Mexico and the Philippines. In M. T. Sinclair (Ed.), Gender, work and tourism (pp. 120-179). London, UK: Routledge.

Cohen, E., \& Cohen, S. A. (2012). Current sociological theories and issues in tourism. Annals of Tourism Research, 39(4), 2177-2202.

Cole, S., \& Ferguson, L. (2015). Towards a gendered political economy of water and tourism. Tourism Geographies, 17(4), 511-528.

Cole, S., \& Morgan, N. (Eds.). (2010). Tourism and inequality: Problems and prospects. Oxford, UK: CABI.

Córdova-Plaza, R. (2015). Universos paralelos. Turismo sexual comercial entre hombres en el Puerto de Veracruz, México. Estudios y Perspectivas en Turismo, 24(4), 848-866.

Corral-Marfil, J. A., \& Cànoves-Valiente, G. (2013). La investigación turística publicada en revistas turísticas y no turísticas: Análisis bibliométrico de la producción de las universidades catalanas. Cuadernos de Turismo, 31, $55-81$.

Costa, C., Breda, Z., Bakas, F. E., \& Durão, M. (2016). "Female charm": Women's role in tourism internationalization, innovation, and networking strategies. In Pappas, 
N. \& I. Bregoli (Eds.), Global dynamics in travel, tourism, and hospitality (pp. 111-129). Hershey, PA: Business Science Reference.

Di Ciommo, R. C. (2007). Turismo, gênero e pesquisa participativa na reserva extrativista marinha do Corumbau. Caderno Virtual de Turismo, 7(2), 1-22.

Díaz-Carrión, I. A. (2014). Ecoturismo y vida cotidiana de las mujeres en Sontecomapan (Veracruz, México). Cuadernos de Turismo, 34, 69-88.

Falcón, S. M., \& Nash, J. C. (2015). Shifting analytics and linking theories: A conversation about the "meaningmaking" of intersectionality and transnational feminism. Women's Studies International Forum, 50, 1-10.

Femenías, M. L. (2009). Género y feminismo en América Latina. Debate Feminista, 40, 42-74.

Ferranti, D., Perry, G., Ferreira, F., \& Walton, M. (2005). Desigualdad en América Latina. Bogotá, Colombia: Banco Mundial, Alfaomega.

Figueroa-Domecq, C., Pritchard, A., Segovia-Pérez, M., Morgan, N., \& Villacé-Molinero, T. (2015). Tourism gender research: A critical accounting. Annals of Tourism Research, 52, 87-103.

García-Ortega, M., \& Marín-Poot, H. M. (2014). Creación y apropiación de espacios sociales en el turismo gay: Identidad, consumo y mercado en el Caribe mexicano. $\mathrm{Cul}$ turales, 2(1), 71-94.

Gentil, F. de C., \& Araujo, M. L. (2014). A parada do Orgulho LGTB no calendário de eventos da cidade e na geração de negócio para a rede hoteleira paulistana. TURyDES, $7(16$ junio/junho $)$.

Guillamón, A., \& Ruiz, C. (2015). Feminismos y lucha por el territorio en América Latina. Revista Pueblos, 64. Retrieved from http://www.revistapueblos.org/?p= 18848

Hall, C. M. (2011). Publish and perish? Bibliometric analysis, journal ranking and the assessment of research quality in tourism. Tourism Management, 32(1), 16-27.

Henderson, K. A. (1994). Perspective on analyzing gender, women, and leisure. Journal of Leisure Research, 26(2), 119-137.

Henderson, K. A., \& Gibson, H. J. (2013). An integrative review of women, gender, and leisure: Increasing complexities. Journal of Leisure Research, 45(2), 115-135.

Henrici, J. (2002). Calling to the money? Gender and tourism in Peru. In M. B. Swain \& J. Momsen (Eds.), Gender/ tourism/fun? (pp. 118-133). Elmsford, NY: Cognizant Communication Corporation.

Inui, Y., Wheeler, D., \& Lankford, S. (2006). Rethinking tourism education: What should schools teach? Journal of Hospitality, Leisure, Sport and Tourism Education, 5(2), 25-35.

Jappelli, T., Nappi, C. A. \& Torrini, R. (2017). Gender effects in research evaluation. Research Policy, 46, 911-924.

Jiménez-Esquinas, G. (2017). "This is not only about culture": On tourism, gender stereotypes and other affective fluxes. Journal of Sustainable Tourism, 25(3), 311-326.

Johnston, L. (2001). (Other) bodies and tourism studies. Annals of Tourism Research, 28(1), 180-201.
Kashima, Y. (2014). How can you capture cultural dynamics? Frontiers in Psychology, 5, 995. doi: 10.3389/ fpsyg.2014.00995

Kinnaird, V., \& Hall, D. R. (Eds.). (1994). Tourism: A gender analysis. Chichester, UK: Wiley.

Lagarde, M. (1996). Género y feminismo. Desarrollo humano $y$ democracia. Madrid, Spain: Horas y Horas.

López-López, Á., \& Carmona-Mares, R. (2008). Turismo sexual masculino-masculino en la Ciudad de México. Teoría y Praxis, 5, 99-112.

López-López, Á., Gallegos, O., \& Quintero, G. (2015). Cuerpos de hombres en venta en ámbitos turísticos de la ciudad de México: Una perspectiva espacial. Estudios y Perspectivas en Turismo, 24(4), 809-824.

López-López, Á., \& Van Broeck, A. M. (2015). Turismo y sexo entre hombres: La complejidad del discurso y la praxis. Estudios Y Perspectivas En Turismo, 24(4), 780-786.

López-Santillán, Á. A., \& Marín-Guardado, G. (2010). Turismo, capitalismo y producción de lo exótico: Una perspectiva crítica para el estudio de la mercantilización del espacio y la cultura. Relaciones. Estudios de historia y sociedad, 31(123), 219-260.

Lunardi, R., de Souza, M., \& Perurena, F. (2015). Participação e Decisão no Turismo Rural: Uma análise a partir da perspectiva de gênero. Revista Turismo Em Análise, 26(2), 334-357.

Marín-Guardado, G. (Ed.). (2015). Sin Tierras No Hay Paraíso: Turismo, organizaciones agrarias y apropiación territorial en México. PASOS, Revista de Turismo y Patrimonio Cultural: El Sauzal, Tenerife.

Marques, A. S., \& Pinho, J. A. (2014). Turismo e Exploração Sexual de Crianças e Adolescentes em Salvador, Bahia: o Estado, a sociedade e a realidade ignorada. Turismo Em Análise, 25(3), 552-579.

Martínez-Corona, B. (2003). Género, sustentabilidad y empoderamiento en proyectos ecoturísticos de mujeres indígenas. La Ventana, 17(julio), 188-217.

Meisch, Lynn A. (1995). Gringas and otavaleños: Changing tourist relations. Annals of Tourism Research, 22(2), 441-462.

Monterrubio, J. C. (2015). Construcciones socioculturales de la playa nudista: Entre lo liminar y el homoerotismo. Estudios y perspectivas en turismo, 24(4), 908-923.

Munar, A. M., Khoo-Lattimore, C., Chambers, D., \& Biran, A. (2017). The academia we have and the one we want: On the centrality of gender equality. Anatolia, 28(4), 582591. doi: 10.1080/13032917.2017.1370786

Nascimento-Duarte, B. (2009). Turismo e relações sociais de sexo. Caderno Virtual de Turismo, 9(2), 72-84.

Norris, J., \& Wall, G. (1994). Gender and tourism. In C. P. Cooper \& A. Lockwood (Eds.), Progress in tourism, recreation and hospitality management, Volume 6 (pp. 57-78). New York, NY: Wiley \& Sons.

Nunkoo, R., Hall, C. M., \& Ladsawut, J. (2017). Gender and choice of methodology in tourism social science research. Annals of Tourism, 63, 203-222. 
Organización Mundial del Turismo (OMT). (2016). Panorama OMT del turismo internacional. Madrid: OMT. Retrieved from http://www.e-unwto.org/doi/pdf/10.18111/ 9789284418152

Organización Mundial del Turismo (OMT) \& ONU Mujeres (2010). Informe mundial sobre las mujeres en el turismo 2010. Madrid, Spain: ONU Mujeres.

Parriault, M.-C., van Melle, A., Basurko, C., GaubertMarechal, E., Maia-Macena, R. H., Rogier, S., Nacher, M. (2015). HIV-testing among female sex workers on the border between Brazil and French Guiana: The need for targeted interventions. Cadernos de Saúde Pública, 31(8), 1615-1622. doi: http://dx.doi.org/10.1590/0102311X00138514

Pérez-Ramírez, C., Zizumbo-Villareal, L., \& MirandaContreras, S. (2012). Incorporación al Turismo Rural y Transformación del Habitus en la Mujer Campesina de San Pedro Atlapulco, México. Rosa Dos Ventos, 4(2), 158-177.

Phillips, R., \& Cree, V. E. (2014). What does the "fourth wave" mean for teaching feminism in twenty-first century social work? Social Work Education, 33(7), 930-943.

Piscitelli,A. (2002). Exotismo e autenticidade: Relatos de viajantes à procura de sexo. Cadernos Pagu, 19. doi: http:// dx.doi.org/10.1590/S0104-83332002000200009

Piscitelli, A. (2007). Sexo tropical em um país europeu: Migração de brasileiras para a Itália no marco do "turismo sexual" internacional. Revista Estudos Feministas, 15(3), 717-744

Platenkamp, V., \& Botterill, D. (2013). Critical realism, rationality and tourism knowledge. Annals of Tourism Research, 41, 110-129.

Pritchard, A., \& Morgan, N. J. (2000). Privileging the male gaze: Gendered tourism landscapes. Annals of Tourism Research, 27(4), 884-905.

Pritchard, A., \& Morgan, N. (2007). De-centring tourism's intellectual universe, or traversing the dialogue between change and tradition. In I. Ateljevic, A. Pritchard, \& N. Morgan (Eds.), The critical turn in tourism studies: Innovative research methodologies (pp. 11-28). Oxford, UK: Elsevier.

Ramos-Maza, T. (2004). Artesanas y artesanías: Indígenas y mestizas de Chiapas construyendo espacios de cambio. LiminaR. Estudios Sociales Y Humanísticos, II (1), $50-71$.

Rebolledo, L. (2001). Impacto de los estudios de género en la democratización de las instituciones de educación superior. La Ventana, 2(13), 75-93.

Rodríguez-Muñoz, G., \& Acevedo-Duarte, A. (2015). Cambios en la vida cotidiana de las mujeres a través de la incorporación al trabajo turístico en la Reserva de la Biosfera de la Mariposa Monarca. El Periplo Sustentable, 29. Retrieved from https://www.redalyc.org/ pdf/1934/193440418008.pdf

Sassen, S. (2007). A sociology of globalization. Análisis Político, 20 (61), 3-27.
Scholz, T. M. L. (2016). Beyond "roaring like lions": Comadrismo, Counternarratives, and the Construction of a Latin American Transnational Subjectivity of Feminism. Communication Theory, 26, 82-101.

Sinclair, M. T. (Ed.) (1997). Gender, work and tourism. London, UK: Routledge.

Small, J., Harris, C. \& Wilson, E. (2017). Gender on the agenda? The position of gender in tourism's high ranking journals. Journal of Hospitality and Tourism Management, 31, 114-117.

Sobreira, M. C., Machado, C. O., Rebouças, C. Q. \& Forte, S. H. (2014). Cenários prospectivos no combate ao turismo sexual internacional em Fortaleza. Visão E Ação, 16(2), 416-449.

Swain, M. B. (1995). Gender in tourism. Annals of Tourism Research, 22(2), 247-266.

Swain, M. B. (2005). Las dimensiones de género en la investigación sobre turismo: Temas globales, perspectivas locales. Politica y sociedad, 42(1), 25-37.

Swirskya, J. M., \& Angelonea, D. J. (2015). Equality, empowerment, and choice: What does feminism mean to contemporary women? Journal of Gender Studies, 25(4), 445-460.

Tribe, J., \& Xiao, H. (2011). Developments in tourism social science (editorial). Annals of Tourism Research, 38(1), 7-26.

Vergara-Figueroa, A., \& Arboleda-Hurtado, K. (2014). Feminismo afrodiaspórico. Una agenda emergente del feminismo negro en Colombia. Universitas Humanistica, 78 (julio-diciembre), 109-134.

Vieira, A. (2007). Turismo GLBTT na Costa do Cacau: Uma alternativa econômica para o sul da Bahia. Cultur. Cultura de Revista E Turismo, 01(01), 12-22.

Vizcaino-Suárez, P., \& Díaz-Carrión, I. A. (2018). Gender in tourism research: Perspectives from Latin America. Tourism Review. Advance online publication.

Vizcaino-Suárez, L. P., Serrano-Barquín, R., Cruz-Jiménez, G. \& Pastor-Alfonso, M. J. (2014, November). El género en la investigación y las políticas turísticas en México. Paper presented at the XVIII Congreso de la Asociación Española de Expertos Científicos en Turismo (AECIT). Benidorm, Spain.

Wilson, E. \& Hollinshead, K. (2015). Qualitative tourism research: Opportunities in the emergent soft sciences. Annals of Tourism Research, 54, 30-47.

Wonders, N., \& Michalowski, R. (2001). Bodies, borders, and sex tourism in a globalized world: A tale of two cities-Amsterdam and Havana. Social Problems, 48(4), $545-571$.

Woodward, K., \& Woodward, S. (2015). Gender studies and interdisciplinarity. Palgrave Communications, 1. Retrieved from https://www.nature.com/articles/ palcomms 201518

Yang, E. C. L., Khoo-Lattimore, C., \& Arcodia, C. (2017). Constructing space and self through risk taking: A case of Asian solo female travelers. Journal of Travel Research, 57(2), 260-272. 
